\title{
Studi Komparatif Kesejahteraan Material Anak Panti Asuhan Sebelum dan Masa COVID-19
}

\author{
Amalia Nurlina*, Ihsana Sabriani Borualogo \\ Prodi Ilmu Psikologi, Fakultas Psikologi, Universitas Islam Bandung, \\ Indonesia. \\ *amalianurlina12@gmail.com, ihsana.sabriani@unisba.ac.id
}

\begin{abstract}
This Study has purpose to compare the material well being of orphanage children in Bandung before and during COVID-19 pandemic. The participan in this study were children and adolescent aged $10-18$ years old ( $\mathrm{N}=89,64 \%$ girls; $36 \%$ boys). Data collection was using cluster random sampling technique. The measuring instruments used were CW-SWBS (Children's Worlds Subjective Well-Being Scale) and CW-MWBS (Children's Worlds Material Well-Being Scale). Data analysis was performed using paired $\mathrm{t}$ test, descriptive statistics using crosstabs and frequencies. Aspects that were seen from material welfare were material deprivation, family economic status, and subjective material well being on the frequency of worrying about the amount of money and food availability. The COVID-19 pandemic had made a decline of all sectors. This situation could certainly affect the material welfare of the orphanage children. The results of this study explain that before the COVID-19 pandemic there were $85.4 \%$ of children and adolescents in orphanages who experienced material deprivation. Meanwhile, during the pandemic, the number of children who reported experiencing material deprivation was lower, namely $69.7 \%$ of children and adolescents in orphanages. With these results, it shows that during the COVID-19 pandemic there was a decrease in children's appreciation of material deprivation of Orphanage's children in Bandung city.
\end{abstract}

Keywords: Children, Covid-19, Material Well Being, Orphanage, Youth .

Abstrak. Penelitian ini bertujuan untuk melihat perbandingan kesejahteraan material anak di panti asuhan Kota Bandung sebelum dan masa pandemi Covid-19. Partisipan penelitian ini adalah anak dan remaja Panti Asuhan yang berusia 10-18 tahun ( $\mathrm{N}=89$; 64\% anak perempuan, 36\% anak lakilaki). Pengambilan data menggunakan teknik sampling cluster random sampling. Alat ukur yang digunakan adalah Children's Worlds yaitu CW-SWBS (Children's Worlds Subjective Well-Being Scale) Children's world dan CW-MWBS (Children's Worlds Material Well-Being Scale) Children's world. Analisa data yang dilakukan menggunakan paired t test, descriptive statistic menggunakan ,crosstabs dan frequencies. Aspek yang dilihat dari kesejahteraan material yaitu material deprivation, family economic status, dan subjective material well being pada frekuensi rasa khawatir terhadap jumlah uang dan memiliki makanan dan minuman setiap hari. Pandemi COVID19 menjadikan semua sektor mengalami penurunan termasuk sektor Panti Asuhan. Keadaan ini tentunya dapat mempengaruhi kesejahteraan material yang dimiliki anak Panti Asuhan. Hasil dalam penelitian ini menjelaskan keadaan sebelum pandemi COVID-19 anak dan remaja Panti Asuhan melaporkan sebanyak $(85.4 \%)$ anak dan remaja Panti Asuhan mengalami material deprivation. Namun saat masa pandemi anak yang melapor mengalami material deprivation lebih rendah sebanyak (69.7\%). Dengan hasil demikian menunjukan bahwa pada masa pandemi COVID-19 terjadi penurunan penghayatan anak mengenai material deprivation di Panti Asuhan Kota Bandung.

Kata Kunci: Anak, Covid-19, Material Well Being, Panti Asuhan, Remaja. 


\section{A. Pendahuluan}

Panti Asuhan diartikan sebagai Lembaga Kesejahteraan Sosial Anak. Dengan adanya keputusan yang diberikan oleh Menteri Sosial Republik Indonesia No.15 Tahun 2010 yang menyatakan bahwa "Lembaga Kesejahteraan Sosial Anak (LKSA) adalah organisasi sosial atau perkumpulan sosial yang melaksanakan penyelenggaraan kesejahteraan sosial anak yang dibentuk oleh masyarakat, baik yang berbadan hukum maupun yang tidak berbadan hukum" (Kementrian Sosial RI, 2010, p.9). Setiap anak memiliki hak yang sama dalam perkembangan maupun pertumbuhannya namun masih terdapat sejumlah anak yang tidak mendapatkan haknya secara utuh karena beberapa faktor, seperti kemiskinan, penelantaran, maupun tidak memiliki orang tua atau keluarga (Teja, 2014), sehingga mereka harus tinggal di panti asuhan. Anak dan remaja dalam Panti Asuhan juga sering memiliki masalah (Borualogo, I. S, 2004).Penelitian ini dilakukan di Kota Bandung, di mana terdapat 53 Panti Asuhan dengan jumlah anak asuh sebanyak 2,092 orang (Dinas Sosial, 2020). Pada tahun 2019, ditemukan penyakit baru yang mengganggu sistem pernafasan yang disebabkan oleh Coronavirus. WHO (2019) memberikan nama kepada penyakit ini sebagai Corona Virus Disease-19 (COVID-19). Penyakit ini menyebar secara cepat ke seluruh dunia, sehingga WHO menyatakan kasus ini sebagai pandemic $(\mathrm{CNN}, 2020)$. Indonesia merupakan salah satu negara dengan jumlah kasus COVID-19 tergolong tinggi, saat ini mencapai 1,298,608 jiwa yang terkonfirmasi positif COVID-19 (Puspa, 2021).

Tentunya pandemi COVID-19 ini memberikan dampak signifikan pada seluruh sektor kehidupan. Beberapa panti asuhan melaporkan terjadinya penurunan jumlah donasi yang diterima selama COVID-19 (Akhyar, 2020). Anak-anak yang berada di panti asuhan juga mengeluhkan pemenuhan kehidupan sehari-hari saat pandemic (Kania, 2020). Penelitian ini dilakukan untuk menginvestigasi efek dari pandemic COVID-19 terhadap kesejahteraan material anak dan remaja yang tinggal di panti asuhan di Kota Bandung. Diener \& Larsen (1984) mengemukakan bahwa kesejateraan materi mengacu pada sumber daya yang dimiliki dan dilaporkan dapat di akses oleh anak-anak.

Penelitian mengenai kesejahteraan material anak masih sangat terbatas dilakukan di Indonesia (Borualogo \& Casas, 2021b), dan belum ditemukan penelitian kesejahteraan material pada anak dan remaja yang tinggal di panti asuhan.

Hasil penelitian Borualogo dan Casas (2021b) pada anak Indonesia menunjukkan bahwa anak-anak usia 10 dan 12 tahun yang datang dari keluarga dengan sosio-ekonomi tinggi menunjukkan skor subjective well-being (SWB) yang lebih tinggi jika dibandingkan dengan anak yang berasal dari keluarga dengan sosio-ekonomi menengah dan rendah. SWB mengacu pada penilaian anak-anak mengenai kualitas hidup mereka, termasuk komponen positif dan negatif (Diener \& Larsen, 1984).

Kesejahteraan material anak diukur melalui kondisi sosio ekonomi keluarga, deprivasi material, ketersediaan makanan dan minuman untuk dikonsumsi setiap hari, dan kekhawatiran akan jumlah uang yang dimiliki keluarga (Borualogo \& Casas, 2021b). Deprivasi material merupakan keadaan dimana seseorang mengalami kekurangan dalam materi hal tersebut dapat mengidentifikasi keadaan miskin (Lau \& Bradshaw, 2018). Konsep ini yang digunakan untuk mengukur kesejahteraan material pada anak dan remaja di panti asuhan dengan mempertimbangkan konteks sosio ekonomi di panti asuhan.

Berdasarkan latar belakang diatas dapat ditarik beberapa rumusan masalah. Adapun rumusan masalah dalam penelitian ini adalah :

1. Bagaimana kesejahteraan material anak dan remaja panti asuhan sebelum pandemi?

2. Bagaimana kesejahteraan material anak dan remaja panti asuhan pada masa pandemic?

3. Apakah terdapat perbedaan kesejahteraan material pada anak dan remaja panti asuhan sebelum dan pada saat pandemic?

\section{B. Metodologi Penelitian}

Pengambilan data penelitian ini dilakukan pada dua periode. Pengambilan data tahun pertama dilakukan pada Februari 2020 sebelum masa pandemik sedangkan pengambilan data tahun kedua dilakukan pada Maret hingga Mei 2021 saat masa pandemik. 
Populasi penelitian ini adalah anak dan remaja Panti Asuhan di Kota Bandung. Teknik sampling yang digunakan adalah cluster random sampling. Yang menjadi cluster adalah tipe panti asuhan, yaitu panti asuhan yang dikelola pemerintah, dikelola swasta, berbasis agama Islam dan non-Islam. Di Kota Bandung terdapat 53 panti asuhan yang kemudian disusun dalam sample framing berdasarkan cluster tersebut. Sejumlah 26 panti asuhan terpilih secara random. Pada tahun pertama, 26 panti asuhan ini setuju untuk berpartisipasi dalam penelitian dengan sample representatif $N=346$. Pada tahun kedua, 4 panti asuhan menolak untuk berpartisipasi dalam penelitian ini karena alasan protokol kesehatan, sehingga hanya 22 panti asuhan yang berpartisipasi pada tahun kedua dengan sampel representatif $N=322$.

Sampel yang berpartisipasi pada tahun pertama, tidak semuanya ikut berpartisipasi pada tahun kedua karena beberapa alasan. Sebagian responden pada tahun pertama, tidak lagi tinggal di panti asuhan pada tahun kedua karena telah kembali ke keluarganya. Sedangkan pada tahun kedua, terdapat sejumlah responden baru yang tidak ikut berpartisipasi pada tahun pertama. Dengan kondisi demikian, karena penelitian ini bertujuan untuk meneliti kesejahteraan material anak dan remaja panti asuhan pada masa sebelum dan saat pandemik, maka sampel yang disertakan dalam penelitian ini adalah sampel yang mengikuti pengambilan data di tahun pertama (sebelum pandemik) dan tahun kedua (saat pandemik) dengan $N=89$.

Alat ukur yang digunakan dalam penelitian ini adalah Children's Worlds Subjective Well-Being Scale (CW-SWBS) yang telah diadaptasi untuk digunakan di Indonesia (Borualogo \& Casas, 2019). CW-SWBS terdiri dari 5 pertanyaan, yaitu: (1) "Saya menikmati kehidupan saya", (2) "Kehidupan saya berjalan dengan baik", (3) "Saya memiliki kehidupan yang baik", (4) "Hal-hal yang terjadi dalam kehidupan saya sangat baik", dan (5) "Saya senang dengan kehidupan saya". CW-SWBS5 menggunakan skala 11-points, di mana $0=$ "Sama sekali tidak setuju" dan $10=$ "Benar-benar setuju". Nilai Alpha Cronbach's pada sampel ini $=.972$.

Kesejahteraan material diukur melalui sejumlah pertanyaan mengenai status ekonomi keluarga, deprivasi material, kekhawatiran mengenai kondisi keuangan keluarga, dan apakah mereka memiliki cukup makanan untuk dimakan setiap hari (Borualogo \& Casas, 2021b) .

Status ekonomi keluarga diukur dengan menanyakan kepada anak dan remaja apakah panti asuhan mereka memiliki listrik, air bersih untuk mandi dan mencuci, air bersih untuk minum, toilet yang tersedia sabun dan air untuk menyiram, sebuah computer, sebuah TV, sebuah kulkas, sebuah radio, sebuah telefon, dan sebuah mobil (Borualogo \& Casas, 2021b). Kategorisasi status ekonomi panti asuhan ditentukan berdasarkan jumlah jawaban Ya atas pertanyaan-pertanyaan tersebut. Anak yang menjawab Ya pada 10 pertanyaan tersebut, dikategorikan sebagai panti asuhan dengan status ekonomi tinggi, anak yang menjawab Ya pada 5-9 pertanyaan tersebut, dikategorikan sebagai panti asuhan dengan status ekonomi sedang, dan anak yang menjawab Ya pada 0-4 jawaban dikategorikan sebagai panti asuhan dengan status ekonomi rendah (Borualogo \& Casas, 2021b).

Deprivasi material diukur dengan menanyakan kepada anak terkait kepemilikan benda-benda secara pribadi, yaitu pakaian dengan kondisi yang bagus, uang yang cukup untuk karyawisata sekolah, akses internet di panti asuhan, barang-barang untuk kebutuhan olahraga dan hobi, uang saku untuk keperluan pribadi, dua pasang sepatu dalam kondisi bagus, sebuah handphone, dan perlengkapan yang dibutuhkan untuk sekolah (Borualogo \& Casas, 2021b).

Kesejahteraan material diukur melalui dua pertanyaan, yaitu seberapa sering anak khawatir mengenai kondisi keuangan panti asuhan, serta apakah mereka memiliki cukup makanan untuk dimakan setiap hari. Kedua pertanyaan ini menggunakan skala 4-point di mana 1 = "Tidak pernah", 2 = "Kadang-kadang", 3 = "Sering", dan 4 = "Selalu" (Borualogo \& Casas, 2021b).

Untuk menguji perbedaan skor mean kesejahteraan material sebelum dan saat pandemik, digunakan paired sample t-test.

\section{Hasil Penelitian dan Pembahasan}

Berdasarkan pembahasan dalam penelitian ini, peneliti menyimpulkan beberapa hasil penelitian sebagai berikut: 


\section{Karakteristik Responden}

Tabel 1. Karakteristik Subjek Penelitian pada Tahun 2020 dan 2021

\begin{tabular}{|c|c|c|c|c|c|c|}
\hline & \multicolumn{2}{|c|}{ Zyempusn } & \multicolumn{2}{|c|}{ Lati-Iakj } & \multicolumn{2}{|c|}{ Total } \\
\hline & Inmlai & $\%$ & trmlah & $\%$ & Inmlsh & $\%$ \\
\hline & \multicolumn{6}{|c|}{ TAHUN 1} \\
\hline$S D$ & 6 & 67 & 12 & 13.5 & 18 & 20.2 \\
\hline SMP & 29 & 32.6 & 16 & 18 & 45 & 50.6 \\
\hline SMA & 22 & 24.7 & 4 & 4.5 & 26 & 29.2 \\
\hline \multirow[t]{2}{*}{ Total } & 57 & 64 & 32 & $\vdots 6$ & 89 & 100 \\
\hline & \multicolumn{6}{|c|}{ TAHNN 2} \\
\hline$S D$ & 3 & 3.4 & 10 & $1: .2$ & 13 & 14.6 \\
\hline SMP & 24 & 27 & 13 & 14.6 & 37 & 42.6 \\
\hline SMA & 30 & $3: .7$ & 9 & 10.1 & 39 & 43.8 \\
\hline Jotal & 57 & 64 & 32 & $\vdots 6$ & 89 & 100 \\
\hline
\end{tabular}

Tabel 4.1 memperlihatkan karakteristik responden pada tahun 1dan tahun 2 berdasarkan jenjang sekolah dan jenis kelamin $(N=89)$ dimana jumlah responden perempuan $=64 \%$ dan laki-laki $=36 \%$.

\section{Data deskripsi Kesejahteraan Material}

Berikut ini adalah data kasus pada material deprivation, rasa khawatir terhadap jumlah uang, makan dan minum setiap hari pada tingkat family economic status

Tabel 2. Data deskripsi Kesejahteraan Material

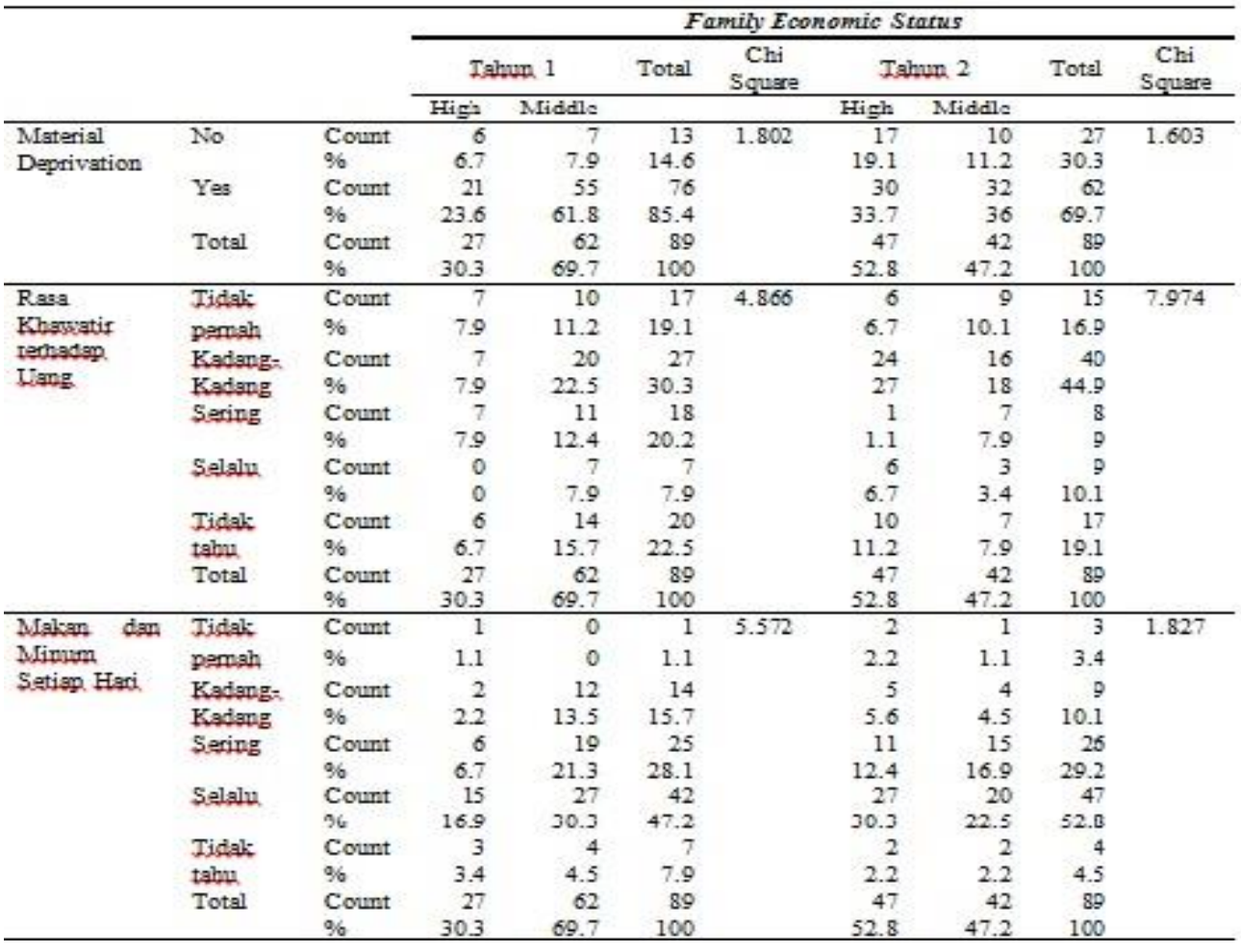

Tabel 2. menunjukan bahwa pada tahun pertama dan tahun kedua terjadi perubahan dimana pada tahun pertama anak dan remaja panti asuh lebih banyak yang mengalami material deprivation pada anak yang memiliki tingkat ekonomi sedang $(85.4 \%)$ dibandingkan pada tahun kedua (69.7\%). Pada rasa khawatir terhadap jumlah uang yang di milikianak dan remaja pada tahun pertama merasakan kadang-kadang mengalami kekhawatiran terhadap jumlah uang yang di miliki oleh Panti Asuhan. Anak dan remaja Panti Asuhan pada rata-rata 
mengatakan selalu merasa khawatir dengan makanan dan minuman untuk sehari-hari (47.2\%) begitupun pada tahun kedua anak dan remaja Panti Asuhan selalu merasa khawatir dengan makanan dan minuman untuk sehari-hari (52.8\%).

\section{Skor rata-rata CW-SWBS}

Berikut ini adalah mean score berdasarkan family economic status, material deprivation, jenis kelamin dan jenjang pendidikan.

Tabel 3. Skor rata-rata CW-SWBS

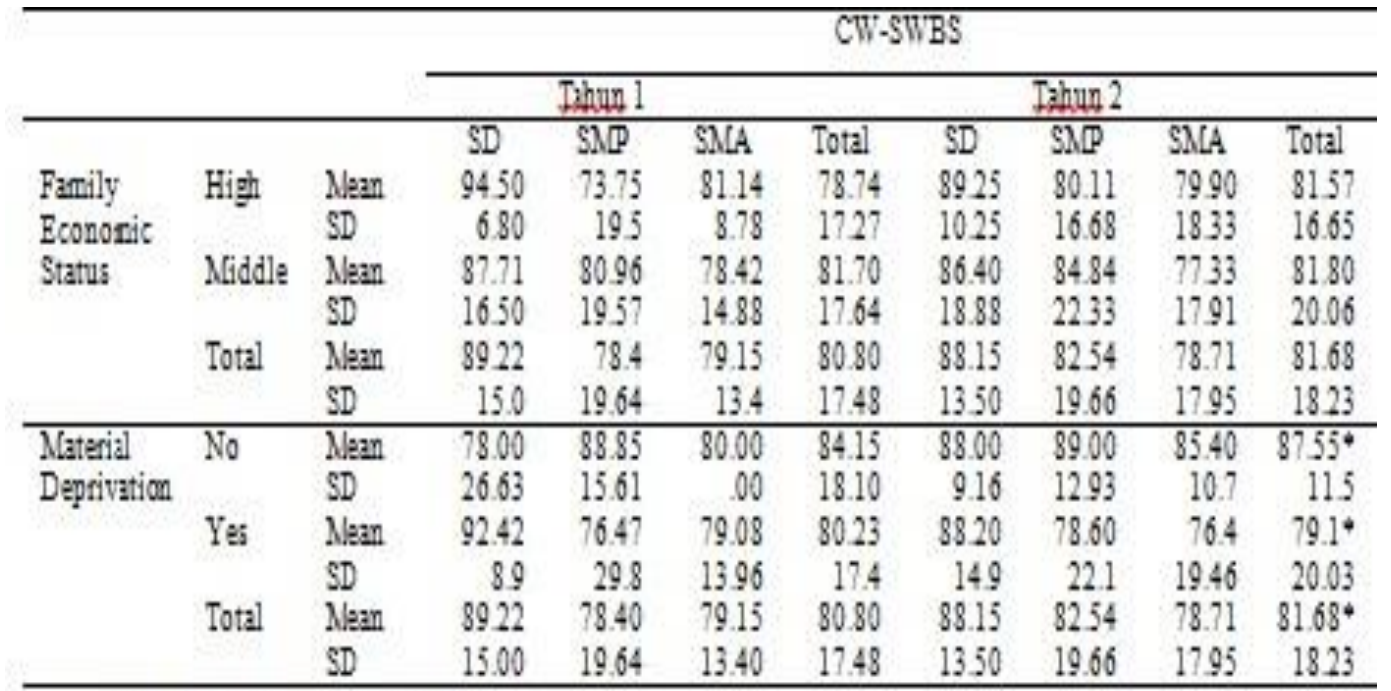

\section{S.gnifikan pada $p<.005$}

Tabel 3. dapat dilihat bahwa tidak terdapat perbedaan yang signifikan SWB pada anak dan remaja Panti Asuhan dengan family economic status tinggi dan sedang pada tahun pertama. Pada anak SD yang dengan family economic status tinggi memiliki skor rata SWB yang cukup tinggi (94.50) sedangkan skor rata-rata yang cukup rendah terdapat pada anak SMP dengan family economic status yang tinggi. Begitupun pada tahun kedua tidak terdapat perbedaan yang signifikan SWB anak dengan family economic status tinggi dan sedang. Remaja SMA memiliki skor rata-rata yang cukup rendah (77.33) dan pada anak SD dengan dengan family economic status tinggi memiliki skor yang cukup tinggi sebesar (89.25). Secara keseluruhan SWB berdasarkan family economic status pada anak dan remaja Panti Asuhan tahun kedua memiliki skor rata-rata cukup tinggi (81.68) dibandingkan dengan skor rata-rata SWB anak dan remaja Panti Asuhan tahun pertama (80.80).

SWB berdasarkan material deprivation tahun pertama anak dan remaja panti asuhan tidak terdapat perbedaan yang signifikan. Anak SD yang mengalami material deprivation justru memiliki skor rata-rata tertinggi (92.42) dan skor rata-rata yang cukup rendah pada remaja SMP yang mengalami material deprivation (76.47). Pada tahun kedua terjadi perbedaan yang signifikan pada anak dan remaja Panti Asuhan yang mengalami material deprivation dengan yang tidak mengalami material deprivation. Anak dan remaja Panti Asuhan yang mengalami material deprivation memiliki skor rata-rata SWB lebih rendah (79.1) dibandingkan dengan anak dan remaja yang tidak mengalami material deprivation (87.55). Secara keseluruhan anak SD memiliti skor rata-rata subjective well being yang cukup tinggi dibandingkan dengan anak SMP dan SMA. 


\section{Paired Sample T Test}

Tabel 4. Paired T-test

\begin{tabular}{|c|c|c|c|c|c|c|c|c|}
\hline \multicolumn{9}{|c|}{ Paired Differences } \\
\hline & & \multirow[t]{2}{*}{ Meen } & \multirow[t]{2}{*}{ SD } & \multirow{2}{*}{$\begin{array}{l}\text { Std. } \\
\text { Error } \\
\text { Mean }\end{array}$} & \multicolumn{2}{|c|}{$\begin{array}{l}95 \% \text { Confidence } \\
\text { Interval of the } \\
\text { Difference }\end{array}$} & \multirow[t]{2}{*}{$\mathrm{t}$} & \multirow[t]{2}{*}{$\begin{array}{l}\text { Sig.(2- } \\
\text { tailed) }\end{array}$} \\
\hline & & & & & Lower & Upper & & \\
\hline $\begin{array}{l}\text { Pair } \\
1\end{array}$ & $\begin{array}{l}\text { CWSWBS_100_TH1 - } \\
\text { cWSWBS_100_TH2 }\end{array}$ & -87640 & 21,76936 & 2,30755 & $-5,46217$ & 3,70936 & -380 &, 705 \\
\hline $\begin{array}{l}\text { Pair } \\
2\end{array}$ & $\begin{array}{l}\text { Family Economic Status } \\
\text { Tahunl - Family } \\
\text { Economic Status Tahun } \\
2\end{array}$ &, 46067 & 1,82816 &, 19379 &, 07557 &, 84578 & 2,377 &, 020 \\
\hline $\begin{array}{l}\text { Pair } \\
3\end{array}$ & $\begin{array}{l}\text { Material Deprivation } \\
\text { Tahun1 - Material } \\
\text { Deprivation Tahum 2 }\end{array}$ &, 65169 & 1,71955 &, 18227 &, 28946 & 1,01391 & 3,575 &, 001 \\
\hline
\end{tabular}

Berdasarkan tabel 4.4 menunjukan bahwa tidak ada perbedaan signifikan antara SWB tahun 1 dan tahun $2(0.705>0.05)$ dan terdapat perbedaan signifikan pada family economic status tahun 1 dan tahun $2(0.020<0.05)$ begitu juga pada Material deprivation $(0.001<0.05)$.

\section{Kesimpulan}

Berdasarkan penelitian yang dilakukan pada 110 anak di Panti Asuhan Kota Bandung dapat disimpulkan bahwa :

Pada masa sebelum COVID-19 jumlah anak yang mengalami material deprivation cenderung lebih tinggi dibandingkan dengan kondisi saat pandemi COVID-19. Hal ini menunjukan bahwa saat pandemi COVID-19 anak-anak panti asuhan lebih sejahtera secara materi dibandingkan dengan sebelum adanya pandemi COVID-19.

SWB anak dan remaja Panti Asuhan melaporkan lebih merasakan sejatera secara materi jika dibandingkan dengan tahun sebelum terjadinya pandemi COVID-19. Secara keseluruhan skor rata-rata SWB anak dan remaja panti asuhan di Kota Bandung masih relatif tinggi dikarenakan memiliki buffer internal dengan cara mengubah cara dalam memandang dirinya sendiri mengenai tantangan homeostatis, memaknai arti dari peristiwa yang merugikan, menghindari tanggung jawab atas kegagalan, atau tidak menganggap penting peristiwa negatif sehingga mampu mempertahakan perasaan yang positif.

Adanya perbedaan kesejahteraan material pada anak dan remaja Panti Asuhan pada tahun pertama dan kedua. Secara keseluruhan anak-anak di Panti Asuhan Kota Bandung masih mengalami Material Deprivation, khawatir terhadap jumlah uang yang dimiliki Panti Asuhan untuk membiayai kehidupan mereka, dan makanan dan minuman yang setiap hari ada.

\section{Acknowledge}

Terimakasih pada pihak terkait yang turut serta dalam membantu peneliti sehingga penelitian ini dapat terlaksana dengan baik.

Ibu Dr. Ihsana Sabriani Borualogo, M.Si, Psikolog selaku dosen pembimbing saya yang senantiasa selalu meluangkan waktunya untuk memberikan arahan, bimbingan, perhatian serta ilmu yang sangat bermanfaat bagi peneliti.

Pihak Panti Asuhan Kota Bandung yang mengizinkan peneliti untuk mengambil data di Panti Asuhan tersebut.

Anak-anak Panti Asuhan Kota Bandung yang telah bersedia menjadi responden dalam penelitian ini.

Semoga Allah SWT senantiasa membalas semua kebaikan yang telah diberikan. Semoga penelitian ini dapat bermanfaat bagi peneliti umumnya kepada para pembaca.

\section{Daftar Pustaka}
[1] Akhyar,
S.
(2020).
Nasib
Panti
Asuhan.

https://banjarmasin.tribunnews.com/2020/08/25/nasib-panti-asuhan

[2] Azwar, S. (2018). Metode Penelitian Psikologi (2nd ed.). Pustaka Pelajar. 
[3]Bono, R., Blanca, M. J., Arnau, J., \& Gómez-Benito, J. (2017). Non-normal distributions commonly used in health, education, and social sciences: A systematic review. Frontiers in Psychology, 8(SEP), 1-6. https://doi.org/10.3389/fpsyg.2017.01602

[4]Borualogo, I. S. (2004). Hubungan antara persepsi tentang figur attachment dengan self esteem remaja panti asuhan Muhammadiyah. Jurnal Psikologi, 13(1), 29-49.

[5] Borualogo, I. S., \& Casas, F. (2019). Adaptation and Validation of The Children's Worlds Subjective Well-Being Scale (CW-SWBS) in Indonesia. Jurnal Psikologi, 46(2), 102. https://doi.org/10.22146/jpsi.38995

[6] Borualogo, I. S., Gumilang, E., Mubarak, A., Khasanah, A. N., Wardati, M. A., Diantina, F. P., Permataputri, I., \& Casas, F. (2019). Process of Translation of the Children's Worlds Subjective Well-Being Scale in Indonesia. 307(SoRes 2018), 180-183. https://doi.org/10.2991/sores-18.2019.42

[7]Borualogo, I. S., \& Casas, F. (2021a). Subjective Well-Being of Bullied Children in Indonesia. Applied Research in Quality of Life, 16(2), 753773.https://doi.org/10.1007/s11482-019-09778-1B

[8] Borualogo, I.S. \& Casas, F. (2021b). Subjective well-being of Indonesian children: A perspective of material well-being. Anima Indonesian Psychological Journal. 36(2)

[9] Casas, F. (2016). Children, Adolescents and Quality of Life: The Social Sciences Perspective Over Two Decades. 3-21. https://doi.org/10.1007/978-3-319-20568-7_1

[10] CNN. (2020). Setahun Lalu Pasien Pertama Covid-19 Ditemukan di Wuhan. CNN Indonesia. $\quad$ https://www.cnnindonesia.com/internasional/20201204124554-113577951/setahun-lalu-pasien-pertama-covid-19-ditemukan-di-wuhan

[11] Deaton, A. (2008). the World : Evidence from the Gallup. 22(2), 53-72.

[12] Dewi Kania. (2020, May). Panti Asuhan Masih Kurang Perhatian saat Pandemi Covid19. Okezone.Com, 1-3. https://lifestyle.okezone.com/read/2020/05/28/612/2221010/pantiasuhan-masih-kurang-perhatian-saat-pandemi-covid-19

[13] Dinas Sosial. (2020). Tahun 2017- Data Panti Asuhan Kota Bandung. Data.Bandung.Go.Id. http://data.bandung.go.id/dataset/a9f84884-36b4-428d-9a768e5e615abd2c/resource/de7378e4-ac27-4832-aca5-d98659098041/download/data-pantiasuhan-kota-bandung-tahun-2017.csv

[14] Fransiska Wijayanti. (2020). Akibat Pandemi Corona, Banyak Donatur Tak Dapat Lagi Biayai Panti Asuhan. Kompastv. https://www.kompas.tv/article/88092/akibat-pandemicorona-banyak-donatur-tak-dapat-lagi-biayai-panti-asuhan

[15] Gross-manos, D. (2017). Children and Youth Services Review Material well-being and social exclusion association with children's subjective Well-being: Cross-national analysis of 14 countries. Children and Youth Services Review, June 2016, 0-1. https://doi.org/10.1016/j.childyouth.2017.06.048

[16] Kementrian Sosial RI. (2010a). Keputusan Menteri Sosial Republik Indonesi. 15.

[17] Kementrian Sosial RI. (2010b). Peraturan Menteri Sosial Republik Indonesia. Menteri Sosial Republik Indonesia, 198. http://www.bphn.go.id/data/documents/14pmsos008.pdf

[18] Kompastv. (2020). Tidak Memiliki Ponsel, Anak-anak di Panti Asuhan Kesulitan Belajar Daring.

[19] Lau, M., \& Bradshaw, J. (2018). Material Well-being, Social Relationships and Children's Overall Life Satisfaction in Hong Kong. Child Indicators Research, 11(1), 185205. https://doi.org/10.1007/s12187-016-9426-7

[20] Main, G., \& Bradshaw, J. (2012). A Child Material Deprivation Index. June, 503-521. https://doi.org/10.1007/s12187-012-9145-7

[21] Main, G., Montserrat, C., Andresen, S., Bradshaw, J., \& Lee, B. J. (2019). Inequality, material well-being, and subjective well-being: Exploring associations for children across 15 diverse countries. Children and Youth Services Review, 97(June), 3-13. https://doi.org/10.1016/j.childyouth.2017.06.033 
[22] Montserrat, C., Casas, F., \& Moura, J. F. (2015). Children's Subjective Well-Being in Disadvantaged Situations. 111-126. https://doi.org/10.1007/978-3-319-17506-5_7

[23] Puspa, H. (2021). 1.298.608 Kasus Covid-19 di Indonesia dan Angka Kematian yang Tak Bisa Ditoleransi. https://jabar.tribunnews.com/2020/04/07/duh-wabah-corona-membuatsumbangan-ke-panti-turun-hingga-80-persen

[24] Ray jordan. (2016). Menteri Sosial: Ada 4,1 Juta Anak Telantar di Indonesia. DetikNews. https://news.detik.com/berita/d-3130939/menteri-sosial-ada-41-juta-anaktelantar-di-indonesia

[25] Teja, M. (2014). Pelindungan terhadap anak telantar di panti asuhan. VI(05). http://berkas.dpr.go.id/puslit/files/info_singkat/Info Singkat-VI-5-I-P3DI-Maret-2014-73.pdf

[26] Tiah SM. (2020). Duh, Wabah Corona Membuat Sumbangan ke Panti Turun hingga 80 Persen Artikel ini telah tayang di tribunjabar.id dengan judul Duh, Wabah Corona Membuat Sumbangan ke Panti Turun hingga 80 Persen, https://jabar.tribunnews.com/2020/04/07/duhwabah-corona-membu. 1-2. https://jabar.tribunnews.com/2020/04/07/duh-wabah-coronamembuat-sumbangan-ke-panti-turun-hingga-80-persen

[27] UNICEF .(2021). Indonesia: Anak dan Remaja Mengalami Dampak Terberat dari Guncangan Ekonomi Akibat COVID-19 - UNICEF dan BKF. https://www.unicef.org/indonesia/id/press-releases/indonesia-anak-dan-remaja-mengalamidampak-terberat-dari-guncangan-ekonomi-akibat. 